\title{
AN ALUMINUM SILOXIDE COMPLEX FOR STEREOSELECTIVE POLYMERIZATION OF RACEMIC LACTIDE
}

\author{
YU ZHANG ${ }^{1,2}$, XUAN PANG ${ }^{l}$, LILI MA ${ }^{1,2}$, ZHAOHUI TANG ${ }^{l, *}$ \\ ${ }^{I}$ Key Laboratory of Polymer Ecomaterials, Changchun Institute of Applied Chemistry, Chinese Academy of Sciences, Changchun, 130022, P. R. China. \\ ${ }^{2}$ University of Chinese Academy of Sciences, Beijing, 100049, P. R. China
}

\begin{abstract}
Stereoselective polymerization of lactide is receiving growing attention in polymer science. Herein, a five-coordinate aluminum siloxide complex, [2,2-dimethyl1,3-propylenebis(3,5-di-tert- butylsalicylideneiminato)] (triphenyl-silanolato) aluminium (III) (1), was prepared from AlEt ${ }_{3}$, N,N'-(2,2-dimethylpropylene) bis(3,5-di-tert-butylsalicylideneimine) and triphenyl-silanol. X-ray analysis demonstrated that $\mathbf{1}$ contained a five-coordinate aluminum atom with distorted trigonal bipyramidal geometry in the solid state. ${ }^{1} \mathrm{H}$ NMR and ${ }^{13} \mathrm{C}$ NMR spectra indicated that the two conformational stereoisomers of 1 tautomerizes rapidly in chloroform or toluene solution at room temperature. 1 showed high stereoselectivity $(\mathrm{Pm}=0.84)$ for the $\mathrm{ROP}$ of $\mathrm{rac}$-lactide in toluene at $100^{\circ} \mathrm{C}$, and polymerized $\mathrm{rac}$-lactide to crystalline polymer $\left(\mathrm{Tm}=178^{\circ} \mathrm{C}\right)$. This is the first report of stereoselective polymerization of $\mathrm{rac}$-lactide using aluminum siloxide as a catalyst.
\end{abstract}

Keywords: aluminum siloxide, catalyst, lactide, stereoselective, polymerization

\section{INTRODUCTION}

Polylactides (PLAs) have received more and more attention in the past two decades due to their increasing environmental, biomedical and pharmaceutical applications. ${ }^{1-5}$ They are usually synthesized by the ring-opening polymerization (ROP) of lactide (LA). Whearas lactides have three different stereoisomers (L-lactide, D-lactide and meso-lactide), so that PLAs have different chain configurations, and the physical and mechanical properties of PLA, as well as its rate of degradation are intimately dependent on the chain stereochemistry (e.g., optically pure PLAs are semicrystalline polymer with melting transition near $180^{\circ} \mathrm{C},{ }^{6}$ atactic PLAs are amorphous polymer, the equivalent mixture of poly(L-lactide) and poly(D-lactide) forms a stereocomplex with a high melting temperature at $230-245^{\circ} \mathrm{C},{ }^{7-9}$ amorphous PLAs degrade more quickly than its crystalline analogues), therefore, the control of the chain configuration of PLAs is very important.

It is well known that many metal alkyl, alkoxide and carboxylate compounds are efficient catalysts for the ROP of lactide. ${ }^{10-19}$ But conventional catalysts and initiators cannot stereoselectively polymerize the different stereoisomers of lactides, the polymerization of $r a c$-LA ( $r a c$-LA is a 1:1 mixture of L-lactide and D-lactide) usually produces atactic PLAs with random placements of $-R R$ and-SS-stereosequences. Spassky et $a l .{ }^{20}$ firstly discovered that $((R)$-SalBinap) AlOMe could polymerize $r a c$-LA to crystalline PLAs with higher Tm $\left(187^{\circ} \mathrm{C}\right)$ than an enantiomerically pure PLA. Subsequently, many other aluminum-Schiff base alkyls and alkoxides were exploited for the stereoselective ROP of LA, ${ }^{21-30}$ especially LAlEt and LAlO'Pr [L= 2,2-dimethyl-1,3-propylenebis(3,5-di-tertbutyl-salicylideneiminato)] were reported to produce crystalline poly( $\mathrm{rac}$ LA) with melting point as high as $201^{\circ} \mathrm{C}$ without requiring any enantiopure compounds. ${ }^{31}$ In this study, an aluminum-Schiff base siloxide complex (1) was synthesized, characterized and firstly used to carry out the stereoselective ROP of $r a c-L A$.

\section{EXPERIMENTAL}

\section{General}

N,N'-(2,2-dimethyl-1,3-propylene)bis(3,5-di-tert-butylsalicylideneimine) were prepared according to reported methods. ${ }^{31} \mathrm{AlEt}_{3}$ (Aldrich) was used as received. Toluene was distilled from $\mathrm{Na}$-benzophenone. Ethyl acetate was distilled from $\mathrm{CaH}_{2}$. rac-Lactide (from Purac) was purified by recrystallization from ethyl acetate and dried under vacuum at room temperature before use. NMR spectra were recorded on Bruker AV 300M, Bruker AV 400M or Bruker $\mathrm{AV} 600 \mathrm{M}$ in $\mathrm{CDCl}_{3}$ or toluene- $d_{8}$ at room temperature. Chemical shifts were given in parts per million from tetramethylsilane (for $\mathrm{CDCl}_{3}$ ) or the impurity in solvent (for toluene- $d_{8}$ ). Gel permeation chromatography (GPC) measurements were carried out using a Waters instrument (515 HPLC pump) equipped with a Waytt interferometric refractometer. GPC columns were eluted with $\mathrm{CHCl}_{3}$ at $25^{\circ} \mathrm{C}$ at $1 \mathrm{~mL} / \mathrm{min}$. The molecular weights were calibrated against polystyrene standards. Differential Scanning Calorimetry (DSC) analyses were determined at a heating rate of $10^{\circ} \mathrm{C} / \mathrm{min}$ on a Perkin Elmer Pyris 1 . The values originated from the second heating scan.

Synthesis of [2,2-dimethyl-1,3-propylenebis(3,5-di-tertbutylsalicylideneiminato)] (triphenyl-silanolato) aluminium (III) (1)

To a stirred solution of $\mathrm{AlEt}_{3}(0.37 \mathrm{~g}, 3.2 \mathrm{mmol}$ in $4 \mathrm{~mL}$ toluene $)$ triphenylsilanol ( $0.89 \mathrm{~g}, 3.2 \mathrm{mmol}$ in $15 \mathrm{~mL}$ toluene) was added dropwise under the protection of argon. The reaction was stirring for $3 \mathrm{hrs}$ at room temperature to yield a clear solution. The mixture was added to a stirred solution of $\mathrm{N}, \mathrm{N}^{\prime}$ (2,2-dimethyl-1,3-propylene)bis(3,5-di-tert-butylsalicylideneimine) (1.71 g, $3.2 \mathrm{mmol}$ ) in $6 \mathrm{~mL}$ of toluene. After being refluxed for $5 \mathrm{hrs}$, the solution was cooled to ambient temperature. Hexane $(4 \mathrm{~mL})$ was added to the solution to produce pale yellow and green rectangular crystals suitable for single-crystal $\mathrm{X}$-ray analysis. Removal of the solvent in the residual crystals under high vacuum at $100{ }^{\circ} \mathrm{C}$ for $48 \mathrm{hrs}$ yielded pale yellow and green powder $(2.17 \mathrm{~g}$, yield $81.2 \%$ ) that was used for elemental analysis. Anal. Calc. for $\mathrm{C}_{53} \mathrm{H}_{67} \mathrm{AlN}_{2} \mathrm{O}_{3} \mathrm{Si}$ C 76.22, H 8.09, N 3.35; Found C 76.29, H 7.55, N 3.45; ${ }^{1} \mathrm{H}$ NMR (400M, $\left.\mathrm{CDCl}_{3}\right): \delta=7.95(\mathrm{~s}, 2 \mathrm{H}, \boldsymbol{H C}=\mathrm{N}), 7.02-7.53(\mathrm{~m}, 23 \mathrm{H}, \mathrm{Ph} \boldsymbol{H}), 3.24\left(\mathrm{~d}, 2 \mathrm{H}, \mathrm{NC} \boldsymbol{H}_{2}\right.$ $\mathrm{J}=12 \mathrm{~Hz}), 2.81\left(\mathrm{~d}, 2 \mathrm{H}, \mathrm{NCH}_{2}, \mathrm{~J}=12 \mathrm{~Hz}\right), 1.43\left(\mathrm{~s}, 18 \mathrm{H}, \mathrm{C}\left(\mathrm{CH}_{3}\right)_{3}\right), 1.35(\mathrm{~s}$, $18 \mathrm{H}, \mathrm{C}\left(\mathrm{CH}_{3}\right), 0.87\left(\mathrm{~s}, 3 \mathrm{H}, \mathrm{C}\left(\mathrm{C} \boldsymbol{H}_{3}\right)\right), 0.85 \mathrm{ppm}\left(\mathrm{s}, 3 \mathrm{H}, \mathrm{C}\left(\mathrm{C} \boldsymbol{H}_{3}\right)\right) \cdot{ }^{13} \mathrm{C} \mathrm{NMR}$ $\left(100 \mathrm{M}, \mathrm{CDCl}_{3}\right): \delta=170.1(\mathrm{HC}=\mathrm{N}), 163.3,140.9,139.4,137.9,135.1,130.4$ 128.3, 126.9, 126.8, 118.3 ( $\boldsymbol{C}$-benzene ring), $67.4\left(\mathrm{NCH}_{2}\right), 35.7$ ( $\boldsymbol{C}$-diamino bridge $), 35.5\left(\boldsymbol{C}\left(\mathrm{CH}_{3}\right)_{3}\right), 34.0\left(\boldsymbol{C}\left(\mathrm{CH}_{3}\right)_{3}\right), 31.4\left(\mathrm{C}\left(\boldsymbol{C H}_{3}\right)_{3}\right), 29.6\left(\mathrm{C}_{(}\left(\mathrm{CH}_{3}\right)_{3}\right), 25.4$, $25.2 \mathrm{ppm}\left(\mathrm{CH}_{3}\right.$-diamino bridge $)$.

Polymerization of rac-lactide using 1

Under the protection of argon, $r a c$-LA $(560.2 \mathrm{mg}, 3.89 \mathrm{mmol})$, powder of complex 1 (147.6 mg, $0.177 \mathrm{mmol})$, and toluene $(7 \mathrm{~mL})$ were added to a dried reaction vessel in an oil bath at $100{ }^{\circ} \mathrm{C}$. After stirring for 12 days, the conversion of monomer was measured by ${ }^{1} \mathrm{H}$ NMR (conversion: $61 \%$ ). The polymer was isolated by precipitation into cold methanol and by centrifugation, and was dried under vacuum at room temperature for 24 hours. The molecule weight $\left(14.4 \times 10^{3} \mathrm{Da}\right)$ of the poly $(\mathrm{rac}-\mathrm{LA})$ was determined via ${ }^{1} \mathrm{H}$ NMR spectrum endgroup analysis. The molecular distribution $(\mathrm{Mw} / \mathrm{Mn}=1.14)$ was measured by GPC. And the $\operatorname{Tg}\left(57.8^{\circ} \mathrm{C}\right)$ and $\operatorname{Tm}\left(176.0^{\circ} \mathrm{C}\right)$ were determined by DSC.

Crystal structure determinations

Single crystal was sealed in a thin-walled glass capillary. Data were collected on a Siemens P4 diffractometer with graphitemonochromated Mo-K $0.71073 \AA$ ) radiation at $293 \mathrm{~K}$, and all calculations were performed using the SHELXL-97 crystallographic software package. The crystal structures were solved by direct method. Refinement was carried out with full matrix leastsquares methods based on $\mathrm{F}^{2}$ in SHELXL-97.

Crystallographic data for the structural analysis have been deposited with the Cambridge Crystallographic Data Centre, CCDC Nos. 210967 for complex 1. Copies of this information may be obtained free of charge from The Director, CCDC, 12 Union Road, Cambridge, CB2 1EZ, UK (Fax: +44-1223-336033; e-mail: deposit@ccdc.cam.ac.uk or www: http://www.ccdc.cam.ac.uk).

Determination of the probability of meso linkages

The parameter $\mathrm{Pm}$ is used to represent probability of meso linkages of poly(rac-LA), which is determined from the homonuclear decoupled ${ }^{1} \mathrm{H}$ NMR of poly(rac-LA). According to first-order Markovian statistics, the probabilities 
of the five tetrad stereosequences of poly(rac-LA $)$ are $[\mathrm{mmm}]=\mathrm{Pm}^{2}+(1-\mathrm{Pm})$ $\mathrm{Pm} / 2,[\mathrm{mmr}]=[\mathrm{rmm}]=(1-\mathrm{Pm}) \mathrm{Pm},[\mathrm{rmr}]=(1-\mathrm{Pm})^{2}$, and $[\mathrm{mrm}]=\left[(1-\mathrm{Pm})^{2}\right.$ $+\operatorname{Pm}(1-\operatorname{Pm})] / 2.32$

\section{RESULTS AND DISCUSSION}

Synthesis and characterization of the aluminum Schiff-base complex 1 The reaction of $\mathrm{AlEt}_{3}$ with equivalent of triphenylsilanol in toluene at room temperature resulted in the formation of a transparent solution that reacted with Schiff-base ligand (N,N'-(2,2-dimethyl-1,3-propylene)bis(3,5-di-tertbutylsalicylideneimine)) in toluene to yield a pale yellow and green solution of $\mathbf{1}$ (Scheme 1). After hexane was added, crystals of $\mathbf{1}$ grew and were isolated from the solution. Pure complex $\mathbf{1}$ was obtained as relatively air-stable powder after removal of the toluene in the crystals. It was readily soluble in toluene or chloroform. Elemental analysis confirmed its composition.

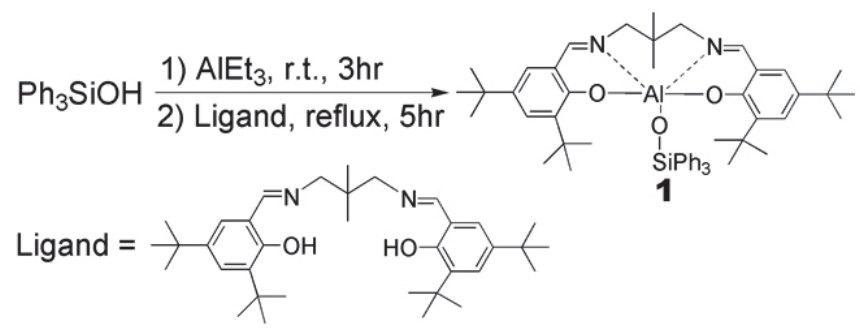

Scheme 1. Preparation of aluminum Schiff-base siloxide.

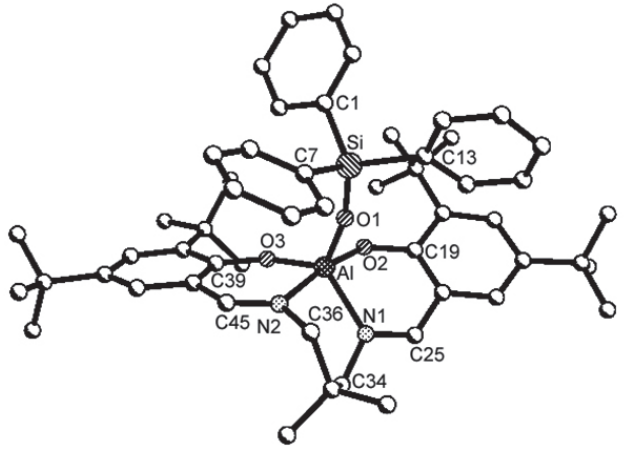

Figure 1. Molecular structure of complex 1.
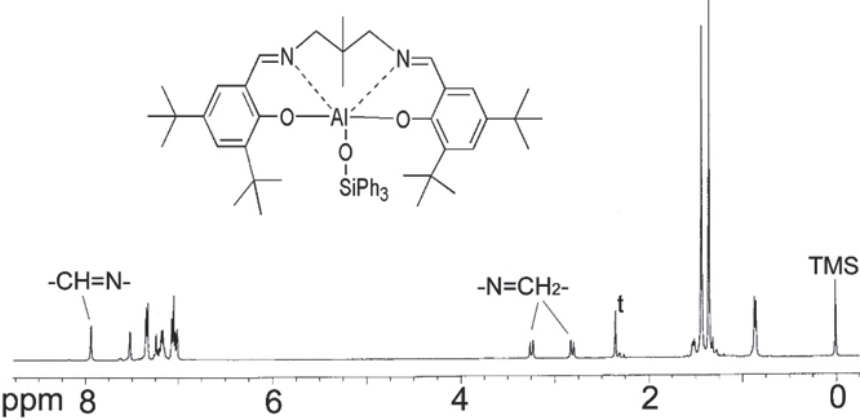

Figure 2. ${ }^{1} \mathrm{H}$ NMR spectrum $\left(400 \mathrm{M}, \mathrm{CDCl}_{3}\right)$ of crystals of $\mathbf{1}$ (t: toluene).

The solid-state structure of $\mathbf{1}$ determinated by X-ray analysis is showed in Figure 1. Crystal data and a summary of data collection and refinement details are given in Table 1. Complex $\mathbf{1}$ contains a five-coordinate central $\mathrm{Al}$ atom. The geometry of five-coordinate aluminum Schiff-base complexes is either square pyramidal (sqp) or trigonal bipyramidal (tbp). $\tau$ can be used to determine how close a distorted complex approximate either sqp or tbp geometry. The $\tau$ value ranges from 0 (perfectly square pyramidal) to 1 (perfectly trigonal bipyramidal) ${ }^{34-36}$ For compound $\mathbf{1}$, the value is 0.77 , which indicates more trigonal bipyramidal geometry in the solid state. It is slightly lower than aluminum Schiff-base isopropoxide $(\tau=0.78),{ }^{31}$ howerver, is somewhat higher

than aluminum Schiff-base ethyl $(\tau=0.76)^{31}$ and Salpen( $\left.{ }^{\mathrm{t}} \mathrm{Bu}\right) \mathrm{AlOSiPh}_{3}(\tau=$ $0.74) .^{34}$ The atoms $\mathrm{O} 2$ and $\mathrm{N} 2$ occupy the axial sites and form an angle of $170.39^{\circ}$, and the $\mathrm{O} 1, \mathrm{O} 3$ and $\mathrm{N} 1$ atoms occupy the equatorial sites that form angles $114.42^{\circ}$ (O1-Al-N1), $120.83^{\circ}$ (O1-Al-O3) and $124.06^{\circ}$ (O3-Al-N1), which differs not significantly from Salpen( $\left.{ }^{ } \mathrm{Bu}\right) \mathrm{AlOSiPh}_{3}$. In comparison with aluminum Schiff-base ethyl and aluminum Schiff-base isopropoxide, 1 shows somewhat large O-Al-N angles $\left(170.39^{\circ}\right.$ and $\left.124.06^{\circ}\right)$. The bond distance of Al-N (equatorial plane) of $\mathbf{1}$ is $1.975 \AA$ that is slightly shorter than those of Salpen('Bu)AlOSiPh $(1.987 \AA)$, the aluminum Schiff-base ethyl $(1.996 \AA)$ and the aluminum Schiff-base isopropoxide (1.983 $\AA$ ) complexes..$^{31,33,34,37}$

In addition to the two singlets corresponding to the protons of the $-\mathrm{C}\left(\mathrm{CH}_{3}\right)_{2}$ - groups at $\delta 0.85$ and $\delta 0.87 \mathrm{ppm}$, the ${ }^{1} \mathrm{H}$ NMR spectrum (Figure 2) of crystals of $\mathbf{1}$ is similar to that of Salpen( $\left.{ }^{(} \mathrm{Bu}\right) \mathrm{OSiPh}_{3}{ }^{33}$ with two singlets for the $-\mathrm{C}\left(\mathrm{CH}_{3}\right)_{3}$ - protons at $\delta 1.35$ and $1.43 \mathrm{ppm}$, two doublets for the $=\mathrm{N}$ $\mathrm{CH}_{2}$ - protons at $\delta 2.81$ and $3.24 \mathrm{ppm}$, one singlet for the $-\mathrm{N}=\mathrm{CH}$ - protons at $\delta 7.95 \mathrm{ppm}$, and the signals corresponding to the protons of the aromatic rings between $\delta 7.02$ and $\delta 7.53 \mathrm{ppm}$. The integral ratio of the signals at $\delta$ $7.95,2.81,1.35$ and $0.85 \mathrm{ppm}$ was $1: 2: 18: 3$. These confirmed the formation of the [2,2-dimethyl-1,3-propylenebis(3,5-di-tert- butylsalicylideneiminato)] (triphenyl-silanolato) aluminium (III).

Table 1. Crystal data and summary of data collection and refinement of $\mathbf{1}$

\begin{tabular}{|c|c|}
\hline Empirical formula & $\mathrm{C}_{56.50} \mathrm{H}_{71} \mathrm{AlN}_{2} \mathrm{O}_{3} \mathrm{Si}$ \\
\hline Temperature & $293(2) \mathrm{K}$ \\
\hline Formula weight & 881.22 \\
\hline Wavelength & $0.71073 \AA$ \\
\hline Crystal system & Triclinic \\
\hline Space group & $\mathrm{P} \overline{1}$ \\
\hline $\mathrm{a}(\AA)$ & $12.417(3)$ \\
\hline $\mathrm{b}(\AA)$ & $14.6486(18)$ \\
\hline $\mathrm{c}(\AA)$ & $17.624(2)$ \\
\hline$\alpha\left({ }^{\circ}\right)$ & $66.057(11)$ \\
\hline $\mathrm{b}\left({ }^{\circ}\right)$ & $86.192(15)$ \\
\hline $1\left({ }^{\circ}\right)$ & $65.405(16)$ \\
\hline $\mathrm{V}\left(\AA^{3}\right)$ & $2643.7(8)$ \\
\hline$Z$ & 2 \\
\hline Density (calculated, $\mathrm{Mgm}^{-3}$ ) & 1.107 \\
\hline Absorption coefficient $\left(\mathrm{mm}^{-1}\right)$ & 0.104 \\
\hline $\mathrm{F}(000)$ & 950 \\
\hline Crystal size $\left(\mathrm{mm}^{3}\right)$ & $0.52 \times 0.42 \times 0.38$ \\
\hline $\mathrm{q}$ range $\left(^{\circ}\right)$ & 1.82 to 25.01 \\
\hline Limiting indices, $h k l$ & -1 to $14,-14$ to $15,-20$ to 20 \\
\hline Reflections collected & 10395 \\
\hline Independent reflections & $8875\left(\mathrm{R}_{\mathrm{int}}=0.0258\right)$ \\
\hline Completeness to $\mathrm{q}=25.01^{\circ}$ & $95.2 \%$ \\
\hline Absorption correction & None \\
\hline Refinement method & Full-matrix least-squares on $\mathrm{F}^{2}$ \\
\hline Data / restraints / parameters & $8875 / 3 / 570$ \\
\hline Goodness-of-fit on $\mathrm{F}^{2}$ & 1.014 \\
\hline Final $R$ indices $[I>2 \sigma(I)]$ & $\mathrm{R} 1=0.0541, \mathrm{wR} 2=0.1054$ \\
\hline $\mathrm{R}$ indices (all data) & $\mathrm{R} 1=0.1217, \mathrm{wR} 2=0.1132$. \\
\hline Largest diff. Peak and hole & 0.548 and $-0.300 \mathrm{e} \AA$ \\
\hline
\end{tabular}




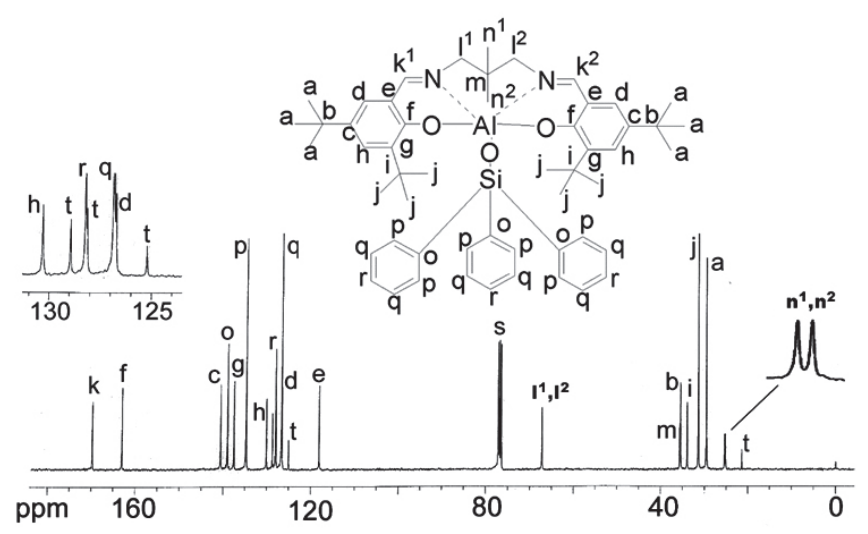

Figure 3. ${ }^{13} \mathrm{C}$ NMR spectrum $\left(100 \mathrm{M}, \mathrm{CDCl}_{3}\right)$ of crystals of $\mathbf{1}$ (t: toluene).

One molecule of toluene and two molecules of $\mathbf{1}$ existed as conformational stereoisomers are found in the triclinic unit cell. The existence of toluene is also confirmed by ${ }^{1} \mathrm{H}$ NMR (Figure 2) and ${ }^{13} \mathrm{C}$ NMR (Figure 3 ) spectra. The peaks at $\delta 21.5,125.3,128.2,129.0 \mathrm{ppm}\left({ }^{13} \mathrm{C} \mathrm{NMR}\right)$ and $2.35 \mathrm{ppm}\left({ }^{1} \mathrm{H} \mathrm{NMR}\right)$ are corresponding to the toluene in the crystals. If the conformational stereoisomers of $\mathbf{1}$ are stable in solution, owing to the distorted tbp geometry, the $-\mathrm{N}=\mathrm{CH}-$ group should show two different resonances in the ${ }^{1} \mathrm{H}$ NMR spectrum and two peaks in ${ }^{13} \mathrm{C} \mathrm{NMR}$, and that, $=\mathrm{N}-\mathrm{CH}_{2}$ - group should show four different signals in the ${ }^{1} \mathrm{H}$ NMR spectrum and two peaks in the ${ }^{13} \mathrm{C}$ NMR spectrum, respectively. Actually, in the ${ }^{1} \mathrm{H}$ NMR spectrum of $\mathbf{1}$ in the chloroform, only one singlet for the $-\mathrm{N}=\mathrm{CH}$ - group $(\delta 7.95 \mathrm{ppm})$ and two doublets for the $=\mathrm{N}$ $\mathrm{CH}_{2}$ - protons ( $\delta 2.81$ and $3.24 \mathrm{ppm}$ ) appear, and in the ${ }^{13} \mathrm{C} \mathrm{NMR}$ spectrum, the $-\mathrm{N}=\mathrm{CH}-(\delta 170.1 \mathrm{ppm})$ and $=\mathrm{N}-\mathrm{CH}_{2}-(\delta 67.4 \mathrm{ppm})$ groups show only one peak, respectively. These phenomena indicate that tautomerization between the two conformational stereoisomers of $\mathbf{1}$ is fast on the NMR scale in the chloroform solution at room temperature, which is similar to aluminum Schiff-base alkyls and aluminum Schiff-base alkoxides. ${ }^{37-40}$ Because the stereoselective polymerization of rac-lactide usually carries out in toluene solution, the nuclear magnetic resonance of $\mathbf{1}$ was also investigated in toluene. In the ${ }^{1} \mathrm{H}$ NMR spectrum of $\mathbf{1}$ in the toluene, one singlet $(\delta 7.95 \mathrm{ppm})$ for the $-\mathrm{N}=\mathrm{CH}$ proton and two doublets ( $\delta 2.65$ and $3.12 \mathrm{ppm}$ ) for the $=\mathrm{N}-\mathrm{CH}_{2}-$ protons are showed. In the ${ }^{13} \mathrm{C}$ NMR spectrum of $\mathbf{1}$ in the toluene, the $-\mathrm{N}=\mathrm{CH}-(\delta 171.3$ ppm $)$ and $=\mathrm{N}_{-} \mathrm{CH}_{2}-(\delta 68.3 \mathrm{ppm})$ groups also show only one peak, respectively. These features suggest that the rapid tautomerization of stereoisomer of $\mathbf{1}$ also exists in the toluene solution. ${ }^{37}$

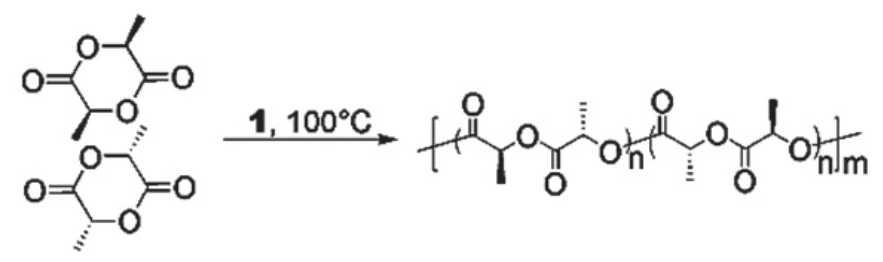

Scheme 2. Stereoselective polymerization of $r a c$-LA using $\mathbf{1}$

The polymerization of $\mathrm{rac}$-LA by 1 was carried out in toluene at $100^{\circ} \mathrm{C}$ in $0.5 \mathrm{M}$ solution of monomer (Scheme 2). Polylactide with $\mathrm{Mn}\left(14.4 \times 10^{3} \mathrm{Da}\right)$ and polydispersity index (1.14) was obtained. The low polydispersity index implied that transesterification was very slight during the ROP of rac-LA. Complex 1 showed high stereoselectivity for the polymerizaiton of $\mathrm{rac}$-LA in toluene at $100^{\circ} \mathrm{C}$. In the homonuclear decoupled ${ }^{1} \mathrm{H}$ NMR spectrum of the poly $(\mathrm{rac}$-LA) synthesized by complex 1 (Figure 4), the $\mathrm{mmm}$ tetrad were the predominant peaks, which manifested that the poly(rac-LA) was dominant isotatic. ${ }^{21-28}$ ${ }^{31}$ The degree of stereoselectivity of compound $\mathbf{1}$, which was defined by the parameter Pm, for this initiator system, $\mathrm{Pm}=0.84$. DSC analysis (Figure 5) manifested that the poly $(\mathrm{rac}-\mathrm{LA})$ using 1 was crystalline $\left(\mathrm{Tm} 178^{\circ} \mathrm{C}\right)$, which indicated the formation of PLA stereocomplex in the polymer. ${ }^{21-28,31}$

\section{CONCLUSIONS}

An aluminum siloxide complex (1) for the stereoselective ROP of lactide was reported in this paper. Complex 1 contains a five-coordinate aluminum atom with distorted trigonal bipyramidal geometry in the solid state. The two conformational stereoisomers of $\mathbf{1}$ tautomerized rapidly on the NMR scale in chloroform or toluene solution at room temperature. 1 showed high stereoselectivity for the ROP of rac-LA in toluene at $100^{\circ} \mathrm{C}$, and polymerized rac-LA to crystalline polymer.

\section{ACKNOWLEDGEMENTS}

This project was financially supported by the National Natural Science Foundation of China, No. 51373168 and 51473029.

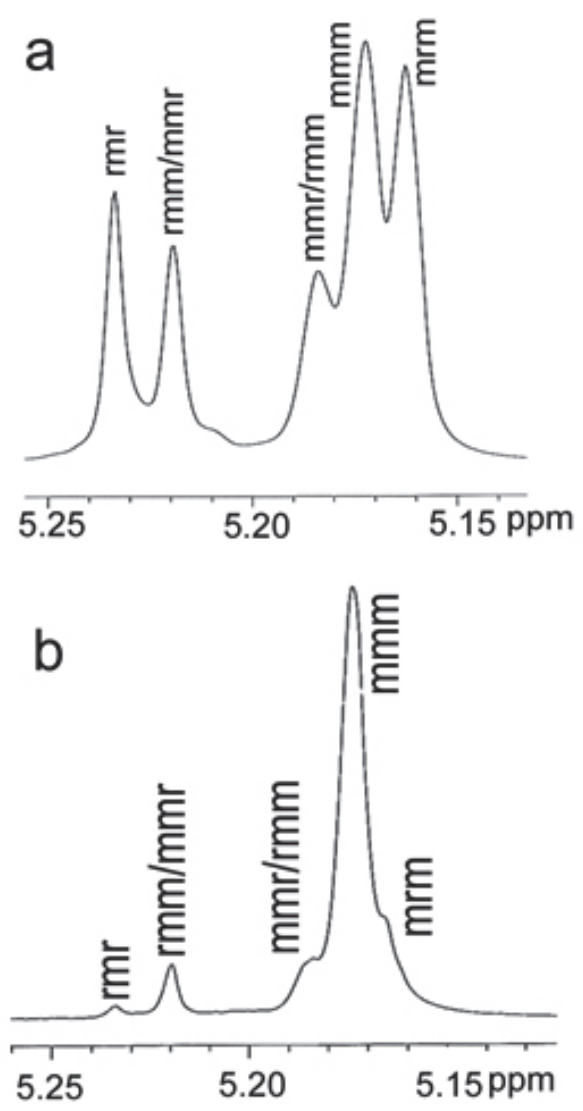

Figure 4. ${ }^{1} \mathrm{H}$ NMR spectra $\left(600 \mathrm{M}, \mathrm{CDCl}_{3}\right)$ of PLAs methine resonances with selected decoupling of PLA methyl resonances: (a) Random poly ( $r a c-L A)$ using $\mathrm{Al}(\mathrm{OiPr})_{3}$; (b) Stereoregular poly $(\mathrm{rac}$-LA) using complex $\mathbf{1}$.

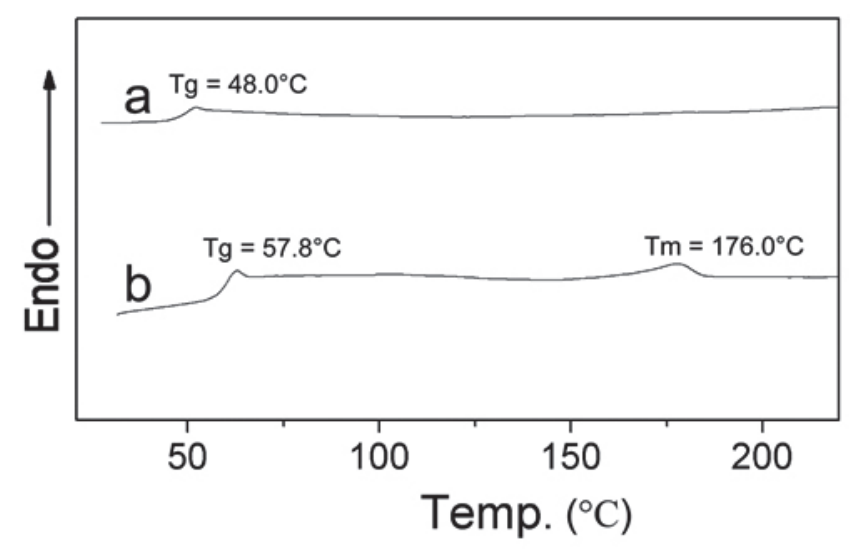

Figure 5. DSC traces (heating rate: $\left.10^{\circ} \mathrm{C} / \mathrm{min}, 2^{\text {nd }} \mathrm{scan}\right)$ of poly $(\mathrm{rac}$-LA $)$ $\mathrm{s}$ : (a) Random poly $(\mathrm{rac}-\mathrm{LA})$ using $\mathrm{Al}(\mathrm{OiPr})_{3}$; (b) Stereoregular poly (rac-LA) using complex 1. 


\section{REFERENCES}

[1] Pang, X., Zhuang, X., Tang, Z.,Chen, X., Biotechnol. J. 5, 1125 (2010).

[2] Sinha Ray, S., Acc. Chem. Res. 45, 1710 (2012).

[3] Pilone, A., Press, K., Goldberg, I., Kol, M., Mazzeo, M.,Lamberti, M., J. Am. Chem. Soc. 136, 2940 (2014).

[4] Song, W., Tang, Z., Lei, T., Wen, X., Wang, G., Zhang, D., Deng, M., Tang, X.,Chen, X., Nanomed. Nanotechnol. Biol. Med. 12, 377 (2016).

[5] Bruna, J. E., Quilodran, H., Guarda, A., Rodriguez, F., Galotto, M. J., Figueroa, P., J. Chil. Chem. Soc. 60, 3009 (2015).

[6] Zhang, X., Mattheus, Goosen, F., Wyss, S.,Pichora, D., J. Macromol. Sci. Polymer Rev. 33, 81 (1993).

[7] Shao, J., Sun, J., Bian, X., Cui, Y., Zhou, Y., Li, G.,Chen, X., Macromolecules 46, 6963 (2013).

[8] Tsuji, H., Horii, F., Hyon, S. H.,Ikada, Y., Macromolecules 24, 2719 (1991).

[9] Sun, J., Shao, J., Huang, S., Zhang, B., Li, G., Wang, X.,Chen, X., Materials Letters 89, 169 (2012).

[10] Honrado, M., Otero, A., Fernández-Baeza, J., Sánchez-Barba, L. F., Garcés, A. s., Lara-Sánchez, A. n.,Rodríguez, A. M., Organometallics 33, 1859 (2014).

[11] Kazakov, O. I., Datta, P. P., Isajani, M., Kiesewetter, E. T.,Kiesewetter, M. K., Macromolecules 47, (2014)

[12] Fliedel, C., Vila $\square$ Viçosa, D., Calhorda, M. J., Dagorne, S.,Avilés, T., ChemCatChem 6, 1357 (2014).

[13] Sauer, A., Kapelski, A., Fliedel, C., Dagorne, S., Kol, M.,Okuda, J., Dalton Trans. 42, 9007 (2013).

[14] Liu, B., Roisnel, T., Guégan, J. P., Carpentier, J. F. o.,Sarazin, Y., Chem. Eur. J. 18, 6289 (2012).

[15] Sarazin, Y., Liu, B., Roisnel, T., Maron, L.,Carpentier, J. F., J. Am. Chem. Soc. 133, 9069 (2011).

[16] Sutar, A. K., Maharana, T., Dutta, S., Chen, C. T.,Lin, C. C., Chem. Soc. Rev. 39, 1724 (2010)

[17] Jones, M. D., Brady, L., McKeown, P., Buchard, A., Schäfer, P. M., Thomas, L. H., Mahon, M. F., Woodman, T. J.,Lowe, J. P., Chem. Sci. 6, 5034 (2015).

[18] Aluthge, D., Ahn, J.,Mehrkhodavandi, P., Chem. Sci. 6, 5284 (2015).

[19] Sun, Z., Duan, R., Yang, J., Zhang, H., Li, S., Pang, X., Chen, W.,Chen, X., RSC Adv. 6, 17531 (2016).
[20] Spassky, N., Wisniewski, M., Pluta, C.,Le Borgne, A., Macromol. Chem. Phys. 197, 2627 (1996)

[21] Yu, I., Acosta-Ramírez, A.,Mehrkhodavandi, P., J. Am. Chem. Soc. 134, 12758 (2012)

[22] Thomas, C. M., Chem. Soc. Rev. 39, 165 (2010)

[23] Bakewell, C., White, A. J., Long, N. J.,Williams, C. K., Angew. Chem. Int. Ed. Engl. 53, 9226 (2014)

[24] Darensbourg, D. J.,Karroonnirun, O., Organometallics 29, 5627 (2010).

[25] Du, H., Velders, A. H., Dijkstra, P. J., Zhong, Z., Chen, X.,Feijen, J., Macromolecules 42, 1058 (2009).

[26] Nomura, N., Chemistry 13, 4433 (2007).

[27] Nomura, N., Akita, A., Ishii, R.,Mizuno, M., J. Am. Chem. Soc. 132, 1750 (2010).

[28] Pang, X., Duan, R., Li, X., Gao, B., Sun, Z., Wang, X.,Chen, X., RSC Adv. 4, 22561 (2014).

[29] Press, K., Goldberg, I.,Kol, M., Angew. Chem. Int. Ed. Engl. 54, 14858 (2015).

[30] Pang, X., Duan, R., Li, X.,Chen, X., Polym. Chem. 5, 3894 (2014).

[31] Tang, Z., Chen, X., Pang, X., Yang, Y., Zhang, X.,Jing, X., Biomacromolecules 5, 965 (2004).

[32] Chamberlain, B. M., Cheng, M., Moore, D. R., Ovitt, T. M., Lobkovsky, E. B.,Coates, G. W., J. Am. Chem. Soc. 123, 3229 (2001)

[33] Atwood, D. A., Hill, M. S., Jegier, J. A.,Rutherford, D., Organometallics 16, 2659 (1997).

[34] Munoz-Hernandez, M. A., Keizer, T. S., Wei, P., Parkin, S.,Atwood, D. A., Inorg. Chem. 40, 6782 (2001).

[35] Tabthong, S., Nanok, T., Kongsaeree, P., Prabpai, S.,Hormnirun, P., Dalton Trans. 43, 1348 (2014).

[36] Addison, A. W., Rao, T. N., Reedijk, J., Rijn, J. v.,Verschoor, G. C., J. Chem. Soc., Dalton Trans. 7, 1349 (1984).

[37] Tang, Z. H., Chen, X. S., Yang, Y. K., Pang, X., Sun, J. R., Zhang, X. F.,Jing, X. B., J. Polym. Sci. A Polym. Chem. 42, 5974 (2004).

[38] Tang, Z., Pang, X., Sun, J., Du, H.,Chen, X., J. Polym. Sci. A Polym. Chem. 44, 4932 (2006).

[39] Tang, Z. H., Yang, Y. K., Pang, X., Hu, J. L., Chen, X. S., Hu, N. H.,Jing X. B., J. Appl. Polym. Sci. 98, 102 (2005).

[40] Tang, Z. H., Chen, X. S., Pang, X., Yang, Y. K., Zhang, X. F.,Jing, X. B., Biomacromolecules 5, 965 (2004) 